DOI: $10.14451 / 2.127 .17$

\title{
ЗНАЧЕНИЕ ПРИНЦИПОВ ПРАВА ДЛЯ СИСТЕМНОГО УРЕГУЛИРОВАНИЯ ПУБЛИЧНЫХ ФИНАНСОВ (ФИНАНСОВО-ПРАВОВЫЕ АСПЕКТЫ)
}

\author{
(c) 2019 Ашмарина Елена Михайлова \\ доктор юридических наук, профессор, академик Российской академии естественных наук (РАEН) \\ зав. кафедрой правового обеспечения экономической деятельности \\ Российский государственный университет правосудия (РГУП) \\ 117418, г. Москва, Новочерёмушкинская ул., д. 69 \\ (c) 2019 Савельев Виктор Николаевич \\ доктор философских наук, профессор, академик Российской академии естественных наук (РАЕН) \\ профессор кафедры правового обеспечения экономической деятельности \\ Российский государственный университет правосудия (РГУП) \\ 117418, г. Москва, Новочерёмушкинская ул., д. 69
}

В статье рассмотрена система общеотраслевых принципов финансового права, их универсальный характер в регуляции финансовых отношений.

Ключевые слова: принцииы финансового права; принции эквивалентности прав и обязанностей субъектов финансовых правоотношений; принцип системного толкования и применения международного и российского права; принции недопустимости обратной силы права; принции недопустимости злоупотребления правом; принцип стабильности правового регулирования финансовых отношений; определенность и неопределенность финансового права.

В качестве вступления отметим, что современное интегративное правопонимание основано на признании принципов в качестве основополагающих форм права. Позитивное (нормативистское) правопонимание (в отличие от интегративного) признает в качестве источников права - только нормы права [6].

Будучи сторонниками концепции интегративного правопонимания и, распространяя эти научные взгляды на такую отрасль публичного российского права, как финансовое право (правовое обеспечение перераспределения в сфере государственных и муниципальных финансов), обратим внимание на следующие теоретические положения. Система форм российского финансового права состоит из двух подсистем, а именно международного финансового права и российского финансового права. В свою очередь каждая подсистема образована составляющими элементами, к которым относятся (в первом случае) основополагающие принципы международного права, международные договоры (содержащие принципы и нормы права), международные обычаи (содержащие принципы и нормы права); во втором случае - основополагающие принци nы российского права, нормативные правовые акты (содержащие принципы и нормы права), нормативные правовые договоры (содержащие принципы и нормы права) и обычаи российского права (содержащие принципы и нормы права) [7]. Эти положения справедливы для обеих подсистем форм финансового права.

Таким образом, принципы финансового права как универсальный социальный алгоритм, будучи (образно говоря) «дорожной картой», указывают направления для дальнейшего правотворчества в стратегически важнейших управленческих процессах как собственно публичными финансами; так и с их помощью всей экономикой государства (ярким примером такого управленческого воздействия служат меры финансового оздоровления, предпринимаемые мегарегулятором - Банком России).

Рассматривая систему принципов финансового права, можно говорить об общеотраслевых принципах и о принципах характерных для финансово-правовых институтов. Например, в качестве основополагающего (общего) принципа как внутригосударственного, так и международного финансового права можно рассматривать принцип эквивалентности прав и обязанностей субъектов финансовых правоотношений (то есть правам одних участников финансовых отношений в точности соответствуют обязанности других: например, правам бюджетополучателей корреспондирует обязанность вышестоящих 
распорядителей бюджетных средств). Если мы теоретически допустим некое отсутствие эквивалентности (нарушение принципа в конкретизирующих его правовых актах), то это очевидно приведет к разбалансировке общественных интересов в сфере публичной финансовой деятельности (бюджетодатель - бюджетополучатель: праву одного суъекта не корреспондирует обязянность другого, и наоборот). Такие казусы могут возникать в текущем правотворчестве стихийно (нарушение правил юридической техники); или даже намеренно (что конечно недопустимо, но возможно).

Среди основополагающих принципов права (в том числе, финансового права) можно назвать (в том числе) принципы системного толкования и применения международного и российского права, недопустимости обратной силы права и недопустимости злоупотребления правом [7]. Последний принцип очень важен в области публичной финансовой (особенно, налоговой!) деятельности.

K принципам международного финансово-экономического права (в большей степени это касается частных финансов) можно отнести также принцип свободы предоставления финансовых услуг; свободы передвижения капитала и ряд других.

Эти и другие принципы представляют собой систему (призваны действовать системно) и находятся во взаимодействии, дополняют друг друга. Например, нарушение принципа эквивалентности прав и обязанностей субъектов финансовых правоотношений может привести к нарушению принципа недопустимости злоупотребления правом. Так (не сектрет), что налоговое законодательство далеко не всегда:

во-первых, формально адекватно экономическому содержанию регулируемых процедур налогообложения [2];

во-вторых, содержит большое количество оценочных понятий, допускающих различное толкование [3];

в-третьих, зачастую даже не соответствует правилам юридической техники [4].

Итак, принципы права, будучи одним из элементов системы форм, играют все более видную роль в современном мире ввиду глобализационных процессов, в результате которых непосредственное применение норм права различных государств (различные правовые системы), представляется затруднительным. Однако, мож- но поставить вопрос: только ли актуальная сегодня ситуация, связанная с необходимостью сближения различных правовых систем ввиду экономической интеграции, характеризуется необходимостью признания за правовыми принципами роли «дорожной карты»? Или универсальные социальные алгоритмы были необходимы и на более ранних исторических фазах становления правового оформления общественных отношений?

На самом деле если мы обратимся к истории, то обнаружим, что еще древнегреческие мыслители отмечали невозможность исчерпывающим образом отразить в законе все многообразие жизненных ситуаций, требующих законодательной регламентации. Так, Платон указывал, что «все относящееся к законодательству никогда и никоем образом еще не было выработано до конца». Аристотель полагал, что многообразие правовых ситуаций не позволяет дать предписания относительно каждого конкретного случая, следовательно, определения законодателя должны носить характер всеобщности, что порождает в ряде случаев неопределенность закона. Таким образом, уже в древности мыслители пришли к заключению о недостижимости абсолютной определенности закона, равно как и о необходимости его конкретизации и толкования. Все это указывает на конструктивное значение интегративного подхода к правопониманию, равно как и на магистральную роль принципов права, роль которых заключается в восполнении существующих нормативных пробелов (при этом применение аналогии закона не представляется предпочтительным выходом) [7].

Однако, следует коротко указать, (подробнее рассмотрим в последующих статьях), что определенность следует рассматривать не столько как принцип, сколько как качество права.

На первый взгляд - мы наблюдаем парадокс (продолжая рассматривать условный пример):

1. нарушение принципа эквивалентности прав и обязанностей субъектов финансовых правоотношений может привести к нарушению принципа не злоупотребления финансовым правом;

2. одновременно нарушение принципа эквивалентности прав и обязанностей субъектов финансовых правоотношений может быть следствием не достаточной определенности правовых актов (допущенной случайно, или даже намеренно). 
Таким образом (в соответствии с построением логического ряда), можно сделать вывод, что нарушение принципа не злоупотребления финансовым правом находится в непосредственной связи и качеством права, а именно его определенностью. Однако, как утверждали еще древние философы, полная определенность не достижима! Какой же видится выход из этой тупиковой ситуации?

Пример: принции эквивалентности прав и обязанностей субъектов финансовых правоотношений непосредственно связан с принципом недопустимости злоупотребления правом.

Например, в соответствии со ст. 252 НК РФ расходами признаются обоснованные и документально подтвержденные затраты, осуществленные налогоплательщиком. На сумму этих затрат налогоплательщик имеет право уменьшить полученные доходы с целью получения налогооблагаемой прибыли. Попробуем разобраться корреспондирует ли это право обязанности налогового органа признать правомерность таких действий (соблюден ли в данном случае принцип эквивалентности прав и обязанностей субъектов финансовых правоотношений)? Итак, налогоплательщик имеет право осуществить уменьшение доходов в двух случаях, если расходы являются:

- являются документально подтвержденными (затраты подтверждаются документами, оформленными в соответствии с законодательством);

- признаются обоснованными (экономически оправданными).

В первом случае мы имеем дело с абсолютно определенно выраженной волей законодателя (подтверждение расходов первичными документами при наличии всех обязательных реквизитов в них), которая не вызывает сомнения.

Что же касается требования экономической оправданности - то этот признак следует признать оценочным (не может быть выработано точного критерия экономической оправданности в различных хозяйственных ситуациях). Одновременно отметим, что речь идет не об основах финансово правового регулирования (в данном случае налогового права), но о порядке исчисления налоговой базы по налогу на прибыль (как представляется, на этом уровне должны оставаться только абсолютно определенные нормы). Таким образом, мы имеем ситуацию когда право налогоплательщика может оказать- ся декларацией и не корреспондировать обязанности налогового органа признать этот зачет оправданным. И в этом случае может возникнуть опасность нарушения принципа не злоупотребления правом со стороны налогового органа. Неопределенность в публичном финансовом и налоговом праве не может быть допущена на уровне такой степени конкретизации, когда регламентируются обязательные элементы налога (ст. 17 НК РФ).

В этой связи поставим основной вопрос: как же преодолеть неопределенность норм права, понимая, что достижение исчерпывающей определенности не представляется возможным?! Думается, что выход был найден и согласимся с теми учеными, которые справедливо обращались к приемам юридической техники, используя такие инструменты как абстрактное формулирование норм, фикция, презумпция, преюдиция.

А именно - основы финансово правового регулирования (построенные на основе принципов права) строятся на основе абстрактного подхода. Абстрактное формулирование основ финансового права позволит осуществить их конкретизацию в пределах существующих подотраслей и институтов права при том, что законодатель сможет обобщить круг однородных финансово-экономических явлений как существующих в конкретный момент времени, так и возможных, исходя из экономических законов (на примере налогового, бюджетного, публичного банковского, публичного страхового и др. аналогичных подотраслей и институтов финансового права).

В этом случае неопределенность может рассматриваться:

- как положительное явление (абстрактные положения, требующие конкретизации, но содержащие элементы систематизации и обобщения) на общеотраслевом уровне финансового права (рамочные нормы, оценочные понятия) предпочтительны на общеотраслевом уровне;

- как отрицательное явление на уровне правового регулирования конкретных финансовых отношений (например, налоговое право ст. 252 НК РФ и т.д.). На уровне институтов финансового права (как и прочих публичных отраслей) предпочтительнее наличие абсолютно определенных норм [1].

Причины неопределенности могут содержаться не только в дефектах юридической тех- 
ники, но и не верном понимании, и правовом оформлении (как следствие) экономических явлений [5]. Например, понимание имманентной экономической сущности банковской и предпринимательской видов деятельности служит критерием разграничения уголовной ответственности по различным составам.

В качестве как приема юридической техники, применяемого с целью преодоления неопределенности в праве используются презумпции, как предположение (пока не доказано обратное). В финансовом праве - это экспериментально установленное предположение, что обычно наблюдаемая связь между фактами, явлениями присуща и данному конкретному случаю. Правовые презумпции закрепляются в нормах права [11]. Презумпции способны упорядочить и систематизировать финансовые отношения.

Целью использования законодателем правовых презумпций - достижение формальной определенности, стабилизация, баланс интересов.

Исключительную роль в регулировании финансовых публичных отношений играет принцип стабильности правового регулирования. Действительно (это очевидно - не будем рассматривать подробно), отсутствие точных хозяйственных ориентиров, установленных в бюджетном и налоговом законодательстве делает невозможной (в лучшем случае - ограниченно возможной) ведение любой коммерческой деятельности, рассчитанной на перспективу.

В заключение обратим внимание на то, что сетевая структура мировой экономики, международное разделение труда, темп научно-технического прогресса и другие факторы со своей стороны дополнительно актуализируют потребность в выработке общезначимых правовых принципов и норм, обеспечивающих устойчивое и стабильное развитие мировой экономики. Важно еще раз подчеркнуть, что принцип всегда ориентирован на форму условности, представляет собой правило, руководство к действию, а факт, как известно, всегда выражается в безусловной форме, он проявляется в нормах права. Вся совокупность правовых конкретных документов формирует в общественном правосознании первичные сведения о правовой действительности, тогда как целостную картину восприятия формируют принципы, в том числе и принципы финансового и экономического видов права, определяющие общую стратегию правового поведения, например, в таких организациях как ООН, ВТО, ЕС, ЕАЭС и в других.

В современном глобальном мире, важнейшей составляющей которого является геоэкономика, международные экономические и правовые принципы деформируются под влиянием крупнейших финансово-промышленных групп и транснациональных корпораций. В этих условиях не международные правила и законы, а принципы прагматизма, выгоды, эгоистической рациональности и интересов элит приобретают уровень глобального регулятора в финансово-экономических отношениях.

Сформированная западная модель глобализации стала размывать грань между биологическими программами регуляции и социальными программами в системе общественных отношений. В итоге мировой экономический порядок регулируют не законы, а интересы.

Определённую роль в процессе формирования целостного финансово-правового поля играет специфика разума человека, ориентированная в первую очередь на мир принципов, символов и образов, которая в сочетании с социальными, экономическими, политическими, правовыми и культурными представлениями формирует реальность, воспринимаемую как целостный порядок.

В завершение, как представляется не будет преувеличением отметить, что через принципы права в финансовых и прочих экономических правоотношениях реализуется баланс частных и публичных интересов.

\section{Библиографический список}

1. Алексеев С. С. Проблемы теории права. Москва. 1972.

2. Ашмарина E.M. Некоторые особенности порядка исчисления в Российской Федерации налога на прибыль организаций и налога на добавленную стоимость // Налоги и налогообложение. 2005. № 1.

3. Ашмарина E.M. Некоторые проблемы современного налогового права в России // Государство и право. 2003. № 3.

4. Ашмарина E.M. Налоговое право и технико-юридические нормы, регулирующие отношения в сфере бухгалтерского учета // Финансовое право. 2004. № Юбилейный. 
5. Ашмарина E.M. О значении содержания предпринимательской и банковской деятельности для рассмотрения судами экономических правонарушений (на примере экономических преступлений в соответствии со ст. 171 и ст. 172 УК РФ) // Аграрное и земельное право. 2017. № 1.

6. Ершов В.В. Основополагающие принципы российского права // Российское правосудие. 2008. № 11.

7. Ершов В.В. Система форм права в Российской Федерации // Российское правосудие. 2009. № 1.

8. Савельев В.Н. История экономики зарубежных стран ../Учебное пособие. Москва. 2017309 с.

9. Савельев В.Н. Историко-правовые проблемы геоэкономики. /Курс лекций. М.: РУСАЙНС, 2018-91 с.

10. Экономическое право Российской Федерации: учебное пособие под ред. Е.М. Ашмариной. Красноярск, 2016363 с.

11. Юридический энциклопедический словарь / под ред. О.Е. Кутафина. Москва. 2002.

12. http://www.consultant.ru/document/cons_doc_LAW_121087/ http://docs.cntd.ru/document/901739101

13. https://yearbook.enerdata.ru/total-energy/world-consumption-statistics.html

14. Сайт 24/7 Уолл-стрит https://sdelanounas.ru/blogs/17066/ http://www.iccwbo.ru/blog/2016/vsemirnaya-torgovaya-organizatsiya-vto/;

15. https://www.bp.com/content/dam/bp/pdf/energy-economics/statistical-review-2016/bp-statistical-review-ofworld-energy-2016-full-report.pdf 